Waste emplacement

The DOE would emplace 10,000 to 11,000 waste packages containing no more than 70,000 metric tons of heavy metal (MTHM) of spent nuclear fuel and high-level radioactive waste in the repository. Of that amount, 63,000 MTHM would be spent nuclear fue assemblies that would be shipped from commercial sites to the repository. The remaining 7,000 MTHM would consist of about 2,333 MTHM of DOE spent nuclear fue and high-level radioactive waste, currently estimated to be approximately 8,315 canisters (the equivalent of 4,667 MTHM).

\section{Repository closure}

After completion of emplacement, the DOE would maintain the repository facilities, including the ventilation system and utilities (air, water and electric) that would enable the continued monitoring and inspection of waste packages, continued investigations of long-term performance, and the retrieval of waste packages, if necessary.

To ensure flexibility for future decisionmakers, the DOE is designing the repository with a capability for closure in as few as $\mathbf{5 0}$ years or as many as 300 years after the start of waste emplacement. For 10,000 years after the repository is closed, people living near Yucca Mountain are expected to receive virtually no increase in radiation exposure.

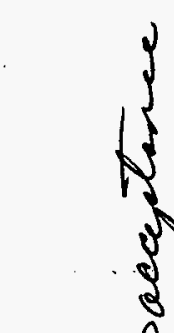

$D C \# 27093$ QA:NA

MOL .20010606 .041

October 2000

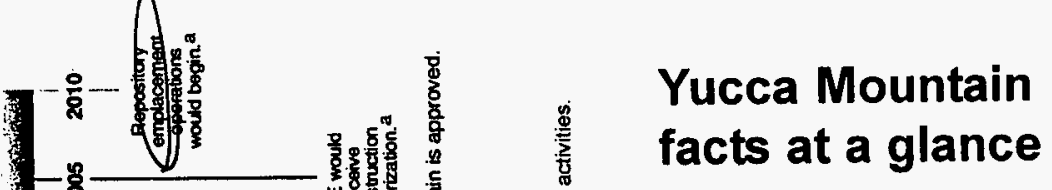

\section{facts at a glance}

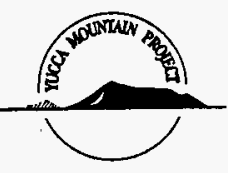

\section{Yucca}

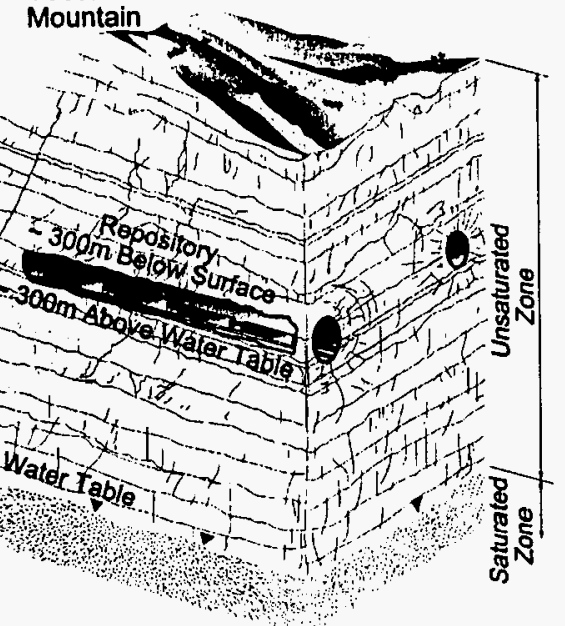

The U.S. Department of Energy (DOE) has been studying Yucca Mountain, Nevada, for more than 20 years to determine its suitability as a geologic repository for the nation's commercial and defense spent nuclear fuotand high-level radioactive waste. An arid otimate, limited surface water, and deep water tables characterize the area. The DOE believes Yucca Mountain is a promising site for a geblogic repository.
Yucca Mountain Sitment of Energy Office of Civilian Radioactive Waste Management 1-800-225-6972 -www.ymp.gov 


\section{Location}

Yucca Mountain is located about 160 kilometers (100 miles) northwest of Las Vegas, Nevada, on federal land in a remote, sparsely populated area of the Mojave Desert. A repository at Yucca Mountain would occupy about 600 square kilometers (230 square miles) of land currently under the control of the DOE, the Nevada Test Site, the U.S. Air Force, and the Bureau of Land Management.

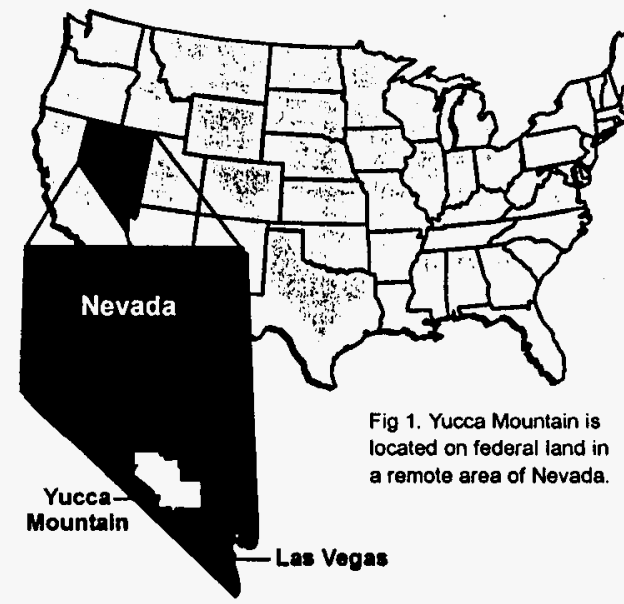

Geology

Yucca Mountain is the product of volcanic activity more than 11 million years ago and of subsequen earth movements. Large-scale volcanism in the area stopped some 7.5 million years ago and the last small eruption was about 75,000 years ago.

Experts conclude that the chance of future

volcanic activity disrupting the site is negligible.
DOE would build the proposed repository and emplace the waste packages in a mass of volcanic rock called welded tuff. These layers of rock have been undisturbed for millions of years.

\section{Water at Yucca Mountain}

Yucca Mountain is located within the Death Valley groundwater basin. Most water evaporates from the soil and other surfaces. Yearly precipitation averages seven inches.

Yucca Mountain and the Death Valley Basin generally lack year-round streams and other bodies of surface water. The nearest groundwater lies 570 to 1,200 feet below the planned repository and does not flow into any rivers that reach the ocean.

\section{Earthquake activity}

DOE has monitored earthquake activity at the Nevada Test Site area since 1978. In 1992, an earthquake measuring 5.6 on the Richter scale occurred at Little Skull Mountain, about 12 miles southeast of Yucca Mountain. It caused no detectable damage in tunnels at either Yucca Mountain or the Nevada Test Site.

Scientific experts have evaluated site data and other relevant information to assess where and how often future earthquakes could occur, how large they could be, and what their impact might be.

\section{Repository design}

DOE would build the repository inside Yucca Mountain between 660 and 1400 feet below the mountain's surface and between 570 and 1,200 feet above the water table.

The repository design takes advantage of the desert environment and geologic features of Yucca Mountain. It includes a long-lived waste package. Analysis of the current design using mathematical models, though subject to uncertainties, indicate the public health and the environment can be protected through natural and engineered barriers.

\section{Site recommendation}

Current assessments of repository performance are encouraging. DOE will submit a report on the site's suitability to the Secretary of Energy in 2001. The Secretary will decide whether to recommend the site to the President.

The Site Recommendation Report will be accompanied by an Environmental Impact Statement.

DOE will refine the design and complete critical tests and analyses before the report is made to the Secretary. More work will be needed before a license application for construction of a repository can be submitted to the

Nuclear Regulatory Commission.

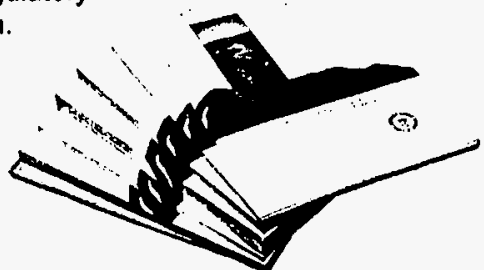

